\title{
Influence of microbial phytase on amino acid digestibility of caecectomised laying hens fed marginally low methionine-based diet
}

\author{
J. O. Agbede ${ }^{\dagger}$ I. A. Adebayo, I. B. Osho and O. M. Bankole \\ Department of Animal Production \& Health, Federal University of Technology, Akure, Nigeria
}

\section{Introduction}

The utilization of phosphorus can be improved and excretion reduced when microbial phytase is included in poultry diets. Thus, by releasing the bond $P$ and enhancing their utilization, dietary supplementation with phytase would be expected to have protein/amino acid (AA) effects in non-ruminant animals. To this end, several studies have demonstrated that the application of phytase causes improvements in ileal amino acid digestibility in broilers and chicks. However, limited published data are available on the effect of phytase on amino acid digestibility in laying hens, especially when the diet is deficient in methionine.This study aims to address this lack of data.

\section{Material and Methods}

Pullets were obtained when they were 16 weeks old from Avian Specialist, (Ibadan, Nigeria) and kept individually in balance crates. The hens were caecectomised when they were between 18 and 22 weeks old. The surgery followed Angkanaporn et al. (1997) and Green et al. (1987) description. The assay followed a $2 \times 2$-factorial arrangement with 2 basal diets. The first diet contained adequate methionine with or without phytase addition while the second diet contained marginally low methionine with or without phytase addition. Fourteen hens were used in two periods. The Ronozyme P 5000 (CT) used was obtained from DSM Nutritional Products, Basel. The hens were randomly allocated to the diets. The hens were fed for 5 days acclimation period and another 5 days of excreta collection period. Each hen was offered an amount of $120 \mathrm{~g} / \mathrm{d}$ of its diet in two equal meals per day at 08:00 and 15:00 h. Feed residues were gathered daily and weighed before and during the excreta collection periods. Feed intake was recorded 5 days before and during excreta collection period. Hens were weighed before and at the end of the excreta collection period. To minimize volatilisation of the excreta, collection were done 3 times per day (07:00, 14:00 and 20:00 h) into separate and pre-weighed plastic buckets. Excreta were freeze dried and analyzed.

Table 1 Amino acid digestibility coefficient of Caecectomised laying hens

\begin{tabular}{|c|c|c|c|c|c|c|c|c|}
\hline \multirow{2}{*}{$\begin{array}{l}\text { Methionine } \\
\text { Phytase }\end{array}$} & \multicolumn{2}{|c|}{ Adequate } & \multicolumn{2}{|c|}{ Low } & \multirow{2}{*}{$\begin{array}{l}\text { Pool } \\
\text { SEM }\end{array}$} & \multicolumn{3}{|c|}{$P$-value (ANOVA) } \\
\hline & No & Yes & No & Yes & & Methionine & Phytase & Met $\times$ Phy \\
\hline Alanine & 0.66 & 0.74 & 0.61 & 0.73 & 0.101 & 0.718 & 0.274 & 0.862 \\
\hline Arginine & 0.76 & 0.79 & 0.74 & 0.78 & 0.082 & 0.814 & 0.582 & 0.874 \\
\hline Aspartic acid & 0.76 & 0.79 & 0.73 & 0.74 & 0.069 & 0.292 & 0.597 & 0.736 \\
\hline Cystine & 0.84 & 0.87 & 0.71 & 0.71 & 0.209 & 0.048 & 0.640 & 0.694 \\
\hline Glutamic acid & 0.63 & 0.68 & 0.62 & 0.65 & 0.088 & 0.772 & 0.535 & 0.912 \\
\hline Glycine & 0.81 & 0.82 & 0.72 & 0.71 & 0.249 & 0.044 & 0.960 & 0.852 \\
\hline Isoleucine & 0.66 & 0.70 & 0.66 & 0.66 & 0.076 & 0.727 & 0.710 & 0.733 \\
\hline Leucine & 0.77 & 0.80 & 0.80 & 0.83 & 0.081 & 0.637 & 0.599 & 0.983 \\
\hline Lysine & 0.77 & 0.79 & 0.74 & 0.81 & 0.082 & 0.958 & 0.461 & 0.722 \\
\hline Histidine & 0.67 & 0.68 & 0.66 & 0.62 & 0.080 & 0.495 & 0.861 & 0.668 \\
\hline Methionine & 0.87 & 0.89 & 0.62 & 0.71 & 0.088 & 0.000 & 0.072 & 0.214 \\
\hline Phenylalanine & 0.81 & 0.83 & 0.73 & 0.79 & 0.070 & 0.121 & 0.262 & 0.703 \\
\hline Proline & 0.80 & 0.82 & 0.67 & 0.68 & 0.114 & 0.251 & 0.899 & 0.978 \\
\hline Serine & 0.73 & 0.78 & 0.67 & 0.62 & 0.101 & 0.242 & 0.987 & 0.583 \\
\hline Threonine & 0.81 & 0.84 & 0.70 & 0.64 & 0.094 & 0.028 & 0.806 & 0.463 \\
\hline Tryosine & 0.73 & 0.80 & 0.71 & 0.71 & 0.073 & 0.198 & 0.493 & 0.484 \\
\hline Valine & 0.78 & 0.81 & 0.74 & 0.75 & 0.072 & 0.281 & 0.702 & 0.840 \\
\hline
\end{tabular}

\footnotetext{
†E-mail: joagbede@yahoo.com
} 
Results

Only cystine and methionine were significantly influenced by dietary methionine level but not with phytase level. This confirms the interrelationship between the cystine and methionine in the metabolism of the two amino acids. Also, threonine was significantly affected by only dietary methionine levels. There was no significant interaction between methoinine and phytase level. Though not significant, phytase addition led to numerical improvement in most of the amino acid digestibility.

\title{
Conclusion
}

These results show that when methionine is marginally deficient in the diet of laying hens, addition of phytase could bring about numerical improvement in the AA digestibility which is not significant. This suggests that the inclusion level of methionine must be met even when phytase is to be used.

\section{Acknowledgement}

The authors gratefully acknowledge the funding received from Alexander von Humboldt, Bonn, Germany.

\author{
References \\ Angkanaporn K, Ravindran V and Bryden WL 1997. British Poultry Science 38, 270-276.
}

Green S, Bertrand SL, Duron MJC and Maillard R 1987. British Poultry Science 28, 643-652.

doi:10.1017/S2040470010000762

\section{Nutrients supply in wethers fed a tropical grass based-diet supplemented with levels of canola meal}

\author{
Fernanda Hentz, Pablo de Souza Castagnino, Tiago Orlandi and Gilberto Vilmar Kozloski ${ }^{\dagger}$
}

Universidade Federal de Santa Maria, Avenida Roraima, 1000, Departamento de Zootecnia, 97105-900 Santa Maria, RS, Brazil

\begin{abstract}
Introduction
Continual growth of the biodiesel industry in Brazil has increased the availability of byproducts, such as canola meal (CM), for use in livestock feeding. However, the nutritional effects of CM supplementation for ruminants fed tropical grass based-diets need to be evaluated. This study evaluated the effect of offering canola meal as a supplementary feed on digestible organic matter intake, microbial protein synthesis, duodenal flux of amino acids and $\mathrm{N}$ retention in wethers fed a tropical grass based-diet.
\end{abstract}

\begin{abstract}
Materials and methods
Eight Polwarth $\times$ Texel crossbreed wethers $(31.1 \pm 3.8 \mathrm{~kg}$ live weight) housed in metabolism cages were used in a replicated $4 \times 4$ Latin Square experiment. Four of them were implanted with duodenal cannulae. Each experimental period was conducted over $15 \mathrm{~d}$, with a $10 \mathrm{~d}$ adaptation and a $5 \mathrm{~d}$ measurement period. Wethers were fed a basal diet consisting of Sudangrass (Sorghum sudanense) ad libitum (100 to $200 \mathrm{~g} / \mathrm{kg}$ of orts) and treatments were not supplementation (control) or supplementation with CM at a rate of 5,10 or $15 \mathrm{~g} / \mathrm{Kg}$ live weight. Forage and supplements were offered separately, in two daily meals, at 0800 and $1700 \mathrm{~h}$. Cracked corn grain was added to CM (1:9) to improve palatability. Feed, refusals, urine and fecal output were recorded and sampled daily on days 10 to 15 of each experimental period. Duodenal sub-samples $(100 \mathrm{~mL})$ were taken on day 15 of each collection period in three hour intervals during a 24-h period. All samples were composited by animal and period. Feed, refusals, duodenal and feces samples were analysed for dry matter (DM), organic matter (OM), N and acid detergent lignin (ADL). Duodenal samples were also analysed for purines and $\alpha$-amino $\mathrm{N}$. Urine samples were analysed for $\mathrm{N}$ concentration. Duodenal flux of DM was estimated based on ADL concentration in duodenal digesta and feces as follows: Duodenal DM $(\mathrm{g} /$ day) $=[$ fecal DM (g/day) $\times$ fecal ADL ( $/ \mathrm{kg}$ of DM)]/duodenal ADL ( $/ \mathrm{kg}$ of DM) (Porter \& Singleton 1971). The amount of microbial $\mathrm{N}$ supplied to the small intestine $(\mathrm{g} / \mathrm{d}$ ) was calculated considering a ratio of purine N/microbial $\mathrm{N}$ of 0.116 (Chen and Gomes, 1992). Duodenal flux $(\mathrm{g} / \mathrm{d})$ of microbial $\mathrm{N}$ and $\alpha$-amino $\mathrm{N}$ were calculated as: [duodenal microbial $\mathrm{N}$ or $\alpha$-amino $\mathrm{N}(\mathrm{g} / \mathrm{kg} \mathrm{DM}) \times$ duodenal DM $(\mathrm{g} / \mathrm{d})$ ]. Data were analyzed using the PROC MIXED option of SAS (2002). When treatment effect was significant means were compared by orthogonal contrast (control vs. supplementation), and the effect of supplementation levels were analysed by regression.
\end{abstract}

\footnotetext{
†E-mail: kozloski@smail.ufsm.br
} 